\title{
An Overview and Synthesis of Research on English Loanwords in Japanese
}

\author{
David Allen \\ Ochanomizu University
}

\begin{abstract}
Loanwords in Japanese that share form and meaning with English words are referred to as Japanese-English cognates (e.g., ラジオ/radzio/ "radio") and are of fundamental concern for researchers concerned with vocabulary learning and instruction. This concern is reflected in the growing body of research into Japanese-English cognates in applied linguistics, which has addressed a wide range of questions in different contexts and with various methodologies. However, the research relevant to applied linguists appears not only in various domestic and international learning- and teaching-focused publications, but also in the feeder disciplines of linguistics, sociolinguistics and psycholinguistics. Consequently, identifying published research on Japanese-English cognates presents a considerable challenge for the applied linguist, which may in turn hinder progression in the field. Therefore, this article reports a comprehensive yet non-exhaustive literature search, which yielded a corpus of 130 research publications, for which a full reference list is provided. Furthermore, an overview and synthesis of the research is given, illustrating how cognates are typically treated in the feeder disciplines and in studies focusing on language learning and/or teaching, and assessment. Based on this synthesis, the following key areas for future research are identified: learners' identification and use of cognates in English, their knowledge of loanwords in Japanese, their attitudes and beliefs towards cognates, researchers' categorisation of cognates, whether classroom teaching approaches to cognates impact learning outcomes, and the extent of the cognate advantage in a range of assessment formats.
\end{abstract}

Keywords: loanword; cognate; Japanese-English; gairaigo; overview; synthesis;

\section{Background}

Around half of the most common 10,000 words in English have been borrowed into Japanese, and around a quarter of the loanwords are highly frequent in Japanese, making them familiar to Japanese speakers (Allen, 2018b). Because of the potential for positive transfer of Japanese L1 knowledge to English language learning, educators have been advised to consider their role in English as a Foreign Language (EFL) learning in Japan (e.g., Daulton, 2008a; Ringbom, 2007). However, research into cognates in applied linguistics is hampered by the fact that relevant studies appear in a wide range of domestic and international publications and across a number of distinct fields of study. Consequently, identifying relevant research 
into Japanese-English cognates presents a considerable challenge for researchers. Therefore, my aim here is to survey the literature on Japanese-English cognates and provide a comprehensive reference list as a resource for facilitating further research. In addition, I provide an overview and synthesis of the research, showing how these cognates are treated differently in three linguistics-related disciplines, while consolidating research in areas relevant to vocabulary learning, teaching and assessment. By doing this, gaps in knowledge are identified for further research which addresses the following three broad questions: (1) How do Japanese-English cognates impact English language learning? (2) How should teachers treat them in the classroom? and (3) How do they affect test performance? After briefly examining the definitions, I will describe the method and findings of the literature review. Finally, I will discuss the possible directions for future loanword research in Japan.

\subsection{Definitions}

This article deals with Japanese-English translation pairs, such as テーブル/teeburu/ and table. From a linguistic perspective, the Japanese word is a loanword derived from a genetically unrelated language, English. From a psycholinguistic perspective, the Japanese and English words are cognate because they are perceived to share both phonological form and meaning. Because this article is primarily focused on language learning and instruction, I will generally use the term Japanese-English cognates to refer to word pairs such as table-テーブル. I will use the term loanword when referring specifically to the Japanese word, particularly in contexts where language learning is not the primary objective of study.

\section{Method}

To survey the literature on Japanese-English cognates, I first searched my own bank of articles and books. Then, using Google Scholar, Academia.edu, ResearchGate, the National Institute of Informatics and the National Diet Library Digital Collections, I searched for articles with the keywords loan, loanword, cognate, gairaigo, Japanese and English. I thereafter examined publications of two Japan-based organisations: Japan Association of Language Teaching (JALT) and Japan Association of College English Teachers (JACET).

As my search generated thousands of hits across various fields, I limited the types of publications and topics. Published work had to be in English, peer-reviewed and freely available on the Internet to those with typical institutional access to academic publications. Unpublished $\mathrm{PhD}$, MA and BA theses, conference abstracts and slides, and articles without full bibliographical information were excluded. Finally, my search was primarily aimed at journal research, but relevant books and chapters were included.

Regarding topics, I focused primarily on research relevant to vocabulary learning, teaching and assessment in the EFL context of Japan. I omitted research in other languages (e.g., English words borrowed from Japanese), lexicography, natural language processing and artificial intelligence. Then, I categorised publications into "feeder disciplines" with three subcategories of "linguistics," 
Table 1. Categorical divisions

\begin{tabular}{llccc}
\hline Category & Subcategory & No. included & Domestic & International \\
\hline Applied linguistics & Learning and Teaching & 54 & 38 & 16 \\
& Assessment & 13 & 8 & 5 \\
Feeder disciplines & Linguistics & 12 & 2 & 10 \\
& Psycholinguistics & 17 & 1 & 16 \\
& Sociolinguistics & 34 & 5 & 29 \\
& Total & 130 & 54 & 76 \\
\hline
\end{tabular}

"psycholinguistics" and "sociolinguistics," and into "applied linguistics" with subcategories of "learning and teaching" and "assessment." This was difficult as many publications seem to cover several subcategories. For example, many books on Japanese loanwords describe both their linguistic and sociolinguistic characteristics. Moreover, because of an abundance of research in the feeder disciplines, I include only what I identified as the most relevant. Needless to say, given the restricted scope, as well as the possibility of having overlooked some research publications, this review should not be treated as a complete history of loanword/ cognate research nor definitive of the popularity of such research in each field.

At the end of the above process, I had identified 130 publications that focused on Japanese-English cognates (Table 1). As Table 1 shows, the majority of applied linguistics research was found in domestic publications, while research in the feeder disciplines tended to be found in international journals. This observation highlights the interest in Japanese-English cognates held by teacher-researchers in Japan as well as their tendency to publish domestically.

An additional 27 articles were identified as relevant, but I was unable to access them online and thus they are not included. In this article, I focus primarily on the applied linguistics papers. However, as the feeder disciplines provide essential background knowledge for applied linguists, I will begin by briefly summarising them.

\section{Results}

\subsection{Linguistics}

Linguists provide descriptions of loanwords based on analysis of form and function, including phonology, morphology, syntax, semantics and pragmatics. They describe the processes involved in loanword adaptation including insertion (epenthesis) and deletion of sounds in the borrowed word so that they fit the Japanese sound structure. Many researchers have provided such linguistic descriptions, in varying degrees of specificity, for instance, Daulton (2008a), Hoffer, Beard and Honna (1983), Irwin (2011), Kay (1995) and Shibatani (1990). These descriptions are useful for understanding Japanese loanwords and how they are adapted from English, and as such may be aimed specifically at English-speaking learners of Japanese (e.g., Igarashi, 2007; Ozaki, 2014). Many linguists also seek to uncover the rules and processes of loanword adaptation, which provide evidence for 
theorising an underlying phonological grammar. The relative importance of phonological knowledge, speech perception and other factors is debated by researchers such as Kaneko and Iverson (2009), Kubozono (2002, 2006) and Smith (2006).

\subsection{Psycholinguistics}

Psycholinguists are interested primarily in the cognitive processes underlying language acquisition and use. Researchers have used Japanese loanwords to investigate how L1 knowledge shapes the perception and production of foreign words/non-words (Dupoux, Kakehi, Hirose, Pallier \& Mehler, 1999; Nomura \& Ishikawa, 2018; Peperkamp, Vendelin \& Nakamura, 2008; Sumiya \& Healy, 2008; Vendelin \& Peperkamp, 2004; Weber, Broersma, \& Aoyagi, 2011; Yazawa, Konishi, Hanzawa, Short \& Kondo, 2015) or how latent L2 knowledge may influence L1 knowledge (Tamaoka \& Miyaoka, 2003). Studies have described the features of Japanese-English cognates (Allen \& Conklin, 2014) and demonstrated cross-linguistic effects with them in masked priming experiments (Allen, Conklin \& Van Heuven, 2015; Ando, Matsuki, Sheridan \& Jared, 2015; Nakayama, Sears, Hino \& Lupker, 2012; Nakayama, Verdonschot, Sears \& Lupker, 2014). Perhaps most relevant, however, is the research that investigates the cognate effect, which refers to the observation that cognates are recognised and produced faster and more accurately than non-cognates. Recent studies have demonstrated the cognate effect in L2 English with L1 Japanese speakers (Allen \& Conklin, 2013; Hoshino \& Kroll, 2008; Lupker, Nakayama \& Perea, 2015; Miwa, Dijkstra, Bolger \& Baayen, 2014; Nakayama, Sears, Hino \& Lupker, 2013; Taft, 2002), revealing that Japanese speakers use L1 knowledge implicitly when using English. The most important factors mediating this effect appear to be L2 proficiency, the degree of perceived phonological and semantic similarity, and cognate frequency.

\subsection{Sociolinguistics}

Sociolinguists provide insights into the social functions of loanwords and what they tell us about the society in which they are used. Research appears in both Japan-oriented journals, such as Japan Forum and Japanese Studies, and English-oriented journals, notably World Englishes and English Today. A solid body of work exists on, broadly speaking, the impact of loanwords on the Japanese language (e.g., Hoffer, 1990; Iwasaki, 1994; Kay, 1995; Loveday, 1996; Stanlaw, 1987, 2004; Tomoda, 1999). Studies describe the social factors influencing the adoption of loanwords (Honna, 1995); government policy towards the adoption of loanwords (Kowner \& Rosenhouse, 2001); the functions and users of loanwords (Hogan, 2003; Honna, 1995; Loveday, 1996; Morrow, 1987; Rebuck, 2002); attitudes towards loanwords varying by age, level of education and profession (Aono, 2014; Loveday, 1996; Matsuda, 2003; Mielick, 2017); and loanword functions within discourse (Hayashi \& Hayashi, 1995) and within specific social groups (Zeserson, 2001). Research has focused on specific text genres in which loanwords are prevalent, such as signs (MacGregor, 2003), advertisements (Sherry \& Camargo, 1987; Takahashi, 1990; Tosa, 2017), magazines (Haarmann, 1986; Rouault \& Okamoto, 2010), television (Ishikawa \& Rubrecht, 2008, 2009) and pop music 
(Moody, 2006). Loanwords also feature in research focused on how English is used in Japan (Barrs, 2011b, 2015; Honna, 1995; Hyde, 2002; Iwasaki, 1994; Kay, 1986; McKenzie, 2008; Seargeant, 2005). Articles discussing "Japanised English" and wasei-eigo reveal not only interest but also concern about this type of English found in Japan (Koscielecki, 2006; Seaton, 2001; Smith, 1974).

\subsection{Applied Linguistics: Learning and Teaching}

Applied linguists seek to understand how cognates are learnt, and how they should be taught, in real-life contexts. In terms of learner populations, Japanese-English cognate research has focused almost exclusively on university/college students, while few studies have dealt with high school (Inagawa, 2007), junior high school (Uchida, 2001, 2007) and elementary school students (Berendt, Kurosaki, Maeda, Matsui, \& Ochi, 2005), and teachers or other populations (Daulton, 2008b; Racine, 2008; Spring, 2018). In terms of stance, most research takes a positive view on cognates while being cognisant of the potential problems that may arise. Only a handful of discursive essays (Martin, 2004; Sheperd, 1996) take a notable negative stance. In the following, I attempt to synthesise research into themes that became apparent during the literature review.

\subsubsection{Word lists}

One research aim has been to identify the proportion of items in English wordlists that are cognate in Japanese; for example, $45.2 \%$ of the 3,000 most frequent words of the BNC (Daulton, 2003b, 2007, 2008a); 47.9\% of 2,918 high-frequency headwords in the BNC (Yokokawa, 2009); 49\% of the 10,000 most frequent words in the BNC-COCA (Allen, 2018b); 59\% or 27\% in the AWL (Allen, 2018b and Daulton, 2005, respectively); and $10.8 \%$ of the first 2,000 words in the JACET 8000 (Barrs, 2013a, 2013b). Other studies have discussed the creation of wordlists with reference to cognates: by using Sketch Engine (Barrs, 2014); by analysing the linguistic environment of 10-year-olds in Japan (Berendt et al., 2005); and by removing cognates (Rogers, Bonnah, Daulton, DuQuette, \& Montgomery, 2017).

\subsubsection{Cognates in English language use}

Cognate use in learner writing has been investigated through paragraph writing (Daulton, 2003c, 2007) and essay writing (Millar, 2006; Struc \& Wood, 2015). Struc and Wood's study is the most comprehensive, utilising a corpus of essays written by 170 learners and 29 native speakers. The authors tentatively conclude that their data support the "borrowed word effect" (Daulton, 2007), that is, a preference for the use of cognates. A preference for cognates over plausible alternatives was also shown in Brown (1995). He used a sentence completion task with four equally plausible options, one of which was a cognate, and found that participants chose the cognate at least twice as often as other options.

Masson (2013) investigated rated word knowledge and accuracy of cognate use in sentence writing for different categories of loanwords. Learners overestimated 
their knowledge of "false friends" most often, but made more errors with the more semantically similar "true" and "convergent" cognates. This finding suggests that L1 knowledge does not necessarily transfer to accuracy in L2 use. Nakao $(2013,2016)$ and Mackenzie (2014) also investigated sentence writing and provided examples of possible phonological and/or semantic interference when using cognates in English.

Learners' receptive knowledge of English cognate words, in addition to false friends and synforms, was investigated by Mackenzie (2014). Learners' knowledge of different senses of cognate English words has been investigated twice (Racine, 2008, 2011). Using a word association task with learners and native speakers, Racine investigated depth of lexical knowledge for English words that were assumed to be cognate or non-cognate in Japanese.

\subsubsection{Knowledge of Japanese loanwords}

Learners' receptive knowledge of loanwords in Japanese has also been investigated. Using pictures, Berendt et al. (2005) checked elementary school students' knowledge of different Japanese loanwords, and different loanword senses (e.g., dark: at night, no light). Other studies have focused on undergraduates' L1 knowledge, and notably have varied in the scale they used to assess familiarity. Daulton (2003b, 2005) has used a triple-choice method (yes/no/don't know). For instance, in Daulton (2003b, 2004a, 2010), he found that of 1,231 Japanese loanwords from Mainichi News Corpus, $75.5 \%$ of all loanwords were recognised; this figure increased to $89 \%$ if they occurred in both the corpus and a loanword dictionary (Daulton, 2003b). Nobis (2012) used a three-point scale $(1=$ not recognised, $2=$ recognized but not used, and $3=$ recognized and used) and found that Japanese learners knew $92 \%$ of a sample $(n=1,292)$ of loanwords drawn from Japanese manga. Finally, Allen (2018b) used ratings on a seven-point scale (from $1=$ I have never used the word to $7=$ I use it every day) and found that learners' familiarity with 246 loanwords of English words from the BNC-COCA correlated significantly $(r=0.75)$ with Japanese corpus frequency data.

Five studies have investigated Japanese students' knowledge of Japanised English (wasei-eigo). In Hatanaka and Pannell (2016), Japanese speakers knew the meanings of all wasei-eigo items but some believed they also existed in English. Meanwhile, Meerman and Tamaoka (2009) observed over 80\% accuracy for the majority of items. Comparing wasei-eigo with loanwords, Kurahashi (2011) argued that "it is more difficult to guess English words from Japanized English loanwords than non-Japanized ones" (p. 111). Finally, in a different type of study, Goddard (2018) replicated Norman (2012) asking learners to categorise words into waseieigo, loanwords or non-words. In both studies, average categorisation accuracy was around $50 \%$, suggesting a potential lack of knowledge about the difference between loanwords and wasei-eigo.

\subsubsection{Categorization of cognates}

A notable feature of research in applied linguistics is the tendency to categorise Japanese-English cognates into different semantic categories. This trend appeared as early as Nagasawa (1958), but more recently has been re-energised by 
Emi Uchida's $\mathrm{PhD}$ research in 2001 in which Japanese loanwords are categorised as true cognates, convergent cognates, divergent cognates, close false friends, distant false friends and Japanised English. Numerous researchers have discussed and/ or utilised this framework (Daulton, 2008a; Masson, 2013; Nakao, 2013; Spring, 2018; Van Benthuysen, 2010). However, Van Benthuysen (2010) makes a pertinent observation: "there can still be some ambiguity and it can be a problem deciding into which category a word should be placed" (p. 258). In another study, Inagawa (2007) made five different categories based on formal and semantic characteristics: (1) straightforward, (2) morphological modification, (3) semantic modification, (4) speech modification and (5) wasei-eigo. Finally, Berendt et al. (2005) used a category scheme for identifying loanwords in Japanese that would be useful for teaching English in the elementary school context. Their scheme was not only context-specific, but also involved distinguishing words based on formal and semantic correspondence.

\subsubsection{Cognate Identification processes}

The factors involved in identifying cognates have received limited attention. In the work of Uchida (2001, 2007), junior high school students wrote the Japanese loanword translation of English words; learners could "guess" half of the cognates based on formal overlap, and although they were initially better at identifying orally presented cognates, their skill in identifying cognates in written form grew over 3 years to equal that of spoken identification. In Van Benthuysen (2004), university students read 30 English words and they wrote the cognate in Japanese if they knew it. Higher proficiency students produced more cognates, suggesting that knowing and/or being able to pronounce the words in English assisted cognate identification. Thus, both Uchida and Van Benthuysen's studies suggest a role of proficiency in cognate identification. In addition, Daulton (2008b) conducted a think-aloud cognate identification task and interviews with two advanced learners to investigate whether they used loanword knowledge to identify words and found that while one reported relying heavily on cognate knowledge, the other did not. This suggests that L2 cognate identification may involve an explicit strategy in addition to the implicit processing demonstrated in psycholinguistic studies.

\subsubsection{Beliefs and attitudes}

Beliefs and attitudes towards cognates have also been of interest to applied linguists (Daulton, 2011; Kurahashi, 2011; Olah, 2007; Spring, 2018), crossing over with the work in sociolinguistics (e.g., Matsuda, 2003). Daulton (2011:11) investigated the hypothesis that a "gairaigo bias" exists among learners, but found those in his study "generally do not suffer from a gairaigo bias." Olah (2007) also investigated university students' views and found little evidence for a negative attitude towards cognates; on the contrary, he also found that students believed they should be taught about them in English classes. In contrast, Kurahashi (2011) reported that her students were "not interested in making use of loanwords for English vocabulary learning” (p. 111). The learners in Daulton's (2011) study did, however, report that their teachers in junior and senior high schools refrained 
from speaking about cognates in class and that, in the learners' views, the teachers did not think they were useful. Spring (2018) followed up on this and interviewed four Japanese teachers of English about their beliefs. He concluded that they had a "gairaigo bias," although this claim was not strongly supported in the interview data. Finally, both researchers (e.g., Sheperd, 1996; Smith, 1997) and students (in Daulton, 2011) appear to agree that pronunciation problems are perhaps the most problematic aspect of Japanese-English cognates.

\subsubsection{Teaching}

Relatively few publications focus solely on teaching cognates. Only four studies describe lesson plans for teaching cognates (Barrs, 2012, 2013c; Rebuck, 2007; Smith, 1997), while others describe lesson ideas and materials for classroom use (Barrs, 2011a; Ferreira, 2011; Simon-Maeda, 1995; Olah, 2007). Most often, recommendations are provided at the end of a paper that is otherwise focused on non-teaching issues. This may reflect an editorial tendency to require recommendations in applied linguistics papers.

One of the most emphasised recommendations has been to teach the English pronunciation of cognates (Martin, 2004; Ogasawara, 2008; Olah, 2007; Smith, 1997). Smith (1997) presents a sample lesson activity and approach to subsequent lessons to raise awareness of, practise and assess the pronunciation of cognate English words.

Many teachers recommend teaching the semantic variations between cognates in Japanese and English. Inagawa (2014) recommends using a corpus approach to make cross-linguistic comparisons, while Rebuck (2007) provides a lesson plan to raise students' awareness of loanword functions in Japanese and the differences in use across languages. Barrs' $(2012,2013 \mathrm{c})$ lesson plan raises awareness of cognate convergence and divergence by focusing on the English visually present in Japanese society. Simon-Maeda (1995) uses an example of negotiation exchange during conversation in which a learner uses a loanword compound that diverges from English usage (i.e., チャームポイント, lit. “charm point," meaning “charming feature"). She suggests presenting such dialogues and having students identify a misused cognate and the interlocutor's repair. Finally, following the trend to categorise cognates, some researchers (Ferreira, 2011; Inagawa, 2007) suggest treating them differently according to their semantic category. To teach these cross-linguistic differences, some researchers advocate using Japanese in the classroom (Uchida, 2007:12), learning Japanese (Daulton, 1998) and learning about loanwords in Japanese (Olah, 2007).

Other researchers advocate the use of word lists in teaching. Barrs (2011a) offers various practical classroom activities for using cognate lists derived from everyday fliers. Ferreira (2011:367) advocates providing students with lists of English-Japanese cognates (e.g., Daulton, 2003a) and having them complete "vocabulary learning sheets," which function as detailed flashcards for explicit vocabulary learning (see also Daulton, 2008a). Olah (2007:185-186) suggests separating English vocabulary lists in textbooks into cognates and non-cognates.

Daulton (1998, 2004b, 2008a) has further recommended that students must have confidence in their intuitions, use context when guessing and learn English 
affixes for productivity. Also, based on her findings, Uchida (2001) suggests presenting cognates firstly in spoken form and then in visual form, especially to beginners with limited word reading abilities. Finally, contrary to the trends noted above, a few authors have suggested not focusing on cognates because they can be assumed to be known (Daulton, 1998; Olah, 2007; Rogers et al., 2017), especially in the case of advanced learners (Daulton, 2005:13).

\subsection{Applied Linguistics: Assessment}

The issue of cognates in tests for Japanese learners of English was discussed at least 20 years ago (Aizawa, 1998), but most articles appeared in the last decade, suggesting an emerging area of research. The studies generally support the claim that English words that are cognate in Japanese are more accurately responded to than those that are not. However, differences exist in how researchers have defined cognates and assessed their impact. Most researchers adopted a binary cognate/non-cognate distinction, while some differentiated cognates in terms of their frequency in Japanese (Allen, 2018a; Bennett \& Stoeckel, 2014). Six studies focused on cognates in tests of vocabulary size (Aizawa, 1998; Allen, 2018a; Jordan, 2012; Laufer \& McLean, 2016; Mizumoto \& Shimamoto, 2008; Willis \& Ohashi, 2012). The study of Laufer and McLean (2016) is one of the more complex designs in terms of distinguishing between both learner proficiencies and test formats (form recall, meaning recall and form recognition). Other studies investigated the cognate effect in multiple-choice receptive tests (Stoeckel \& Bennett, 2013), yes/no tests (Stubbe, 2010, 2014; Stubbe, Hoke \& O’Sullivan, 2013), cloze tests (Rogers, Webb \& Nakata, 2014) and translation tests (Stubbe, 2014; Stubbe et al., 2013; Stubbe \& Yokomitsu, 2012). The work of Mizumoto and Shimamoto (2008) is the only study to consider auditory presentation of cognate items in tests, finding that college students scored significantly higher in the visual mode than the auditory mode, regardless of their proficiency. Only two studies used tasks where test takers must produce a word, or a part of it (Laufer \& McLean, 2016; Rogers et al., 2014).

\section{Conclusions and Future Directions}

While there has been a considerable amount of research conducted regarding cognates in the Japanese EFL context, there are clearly many knowledge gaps remaining. Based on the research themes identified above, I will discuss what I see as areas that require further research.

- Learners' use of cognates in English: The extent to which cross-linguistic factors influence cognate use in English production, both in writing and speech, is far from understood. The fact that learners rely on high-frequency words, and many common cognates are high frequency in English, makes it difficult to explain the apparent preference for cognates in production. This is an interesting yet challenging area for future studies. Also, research has yet to sufficiently demonstrate how knowledge of Japanese loanword senses influences L2 English knowledge and use. 
- Knowledge of loanwords in Japanese: Research shows that learners have a somewhat limited knowledge of loanwords in Japanese, which is unsurprising given the number that exists. However, it is still necessary for researchers to ascertain whether learners know, or are likely to know, the loanwords in a particular study. Further research is thus needed into an objective method of estimating L1 loanword knowledge for specific populations.

- Categorisation of cognates: While some categorisation may be required in certain research designs, it is far from certain that categories, such as "true cognates," "divergent cognates" and "Japanised English," are helpful for learners, teachers or researchers. Future research must consider the validity of such categorical approaches and whether there is any benefit in using them over a simpler, gradient approach to cross-linguistic semantic similarity.

- Cognate identification: There is very little research looking at the role of cognate knowledge in guessing unknown words in authentic English reading and listening tasks. Moreover, little is known about the cognate strategies that learners may employ in such tasks.

- Attitudes and beliefs: There is a distinct lack of rich, qualitative data on teacher and learner views on the teaching and learning of cognates. In-depth interviews, rather than surveys, would provide the kind of data needed to investigate beliefs and attitudes that may impact teaching and learning of cognates.

- Teaching: While many recommendations concerning classroom approaches to cognates have been provided, as well as a few good lesson plans, there is currently no evidence that any of these approaches makes a difference in learning outcomes, in other words, that any of them actually benefits learning above and beyond what is currently done in classrooms. This in itself may explain any perceived reluctance (if there is any) to treat cognates any differently from non-cognates in the classroom.

- Assessment: Future work in assessment must determine whether the cognate advantage extends to a variety of task formats, especially those eliciting productive knowledge. Decisions will also need to be made about how to control for cognates in a variety of tests, not only placement tests but also high stakes tests.

To conclude, I hope to have represented the research on loanwords/cognates in a fair and balanced manner. While I expect some readers may disagree with my categorisations and inferences, I nevertheless hope this review will encourage further research into this fascinating and important area of study.

\section{References}

Aizawa, K. (1998). Developing a vocabulary size test for Japanese EFL learners. ARELE, 9, 75-85.

Allen, D. (2018a). Cognate frequency and assessment of second language lexical knowledge. International Journal of Bilingualism. Published Online: 201806-22. doi:10.1177/1367006918781063 
Allen, D. (2018b). The prevalence and frequency of Japanese-English cognates: Recommendations for future research in applied linguistics. International Review of Applied Linguistics in Language Teaching. Published Online: 2018-02-22. doi: 10.1515/iral-2017-0028

Allen, D., \& Conklin, K. (2013). Cross-linguistic similarity and task demands in Japanese-English bilingual processing. PLoS One, 8(8), e72631.

Allen, D., \& Conklin, K. (2014). Cross-linguistic similarity norms for JapaneseEnglish translation equivalents. Behaviour Research Methods, 46(2), 540-563.

Allen, D., Conklin, K., \& Van Heuven, W. J. B. (2015). Making sense of the Sense Model: Translation priming with Japanese-English bilinguals, The Mental Lexicon, 10(1), 32-52.

Ando, E., Matsuki, K., Sheridan, H., \& Jared, D. (2015). The locus of KatakanaEnglish masked phonological priming effects. Bilingualism, Language and Cognition, 18(1), 101-117.

Aono, K. (2014). Image of English Loanwords in Japanese. Journal of Azabu University, 26, 17-36.

Barrs, K. (2011a). Reconceptualising English in the Japanese Language as an L2 Lexical Resource for Teachers and Learners. Between the Keys, 19(2), 10-15.

Barrs, K. (2011b). Unlocking the encoded English vocabulary in the Japanese language. English Today, 27(3), 15-20.

Barrs, K. (2012). Photographing, uploading and discussing English words in Japanese society. The Language Teacher, 36(5), 42-43.

Barrs, K. (2013a). Categorising English loanwords in Japanese. Vocabulary Education and Research Bulletin, 2(1), 2-3.

Barrs, K. (2013b). High frequency English vocabulary as high frequency loanwords in Japanese. Vocabulary Education and Research Bulletin, 2(2), 8-9.

Barrs, K. (2013c). L2 vocabulary in the L1 environment. Working Papers in Language Education and Research, 1(1), 3-10.

Barrs, K. (2014). Lexical Semantics of English Loanwords in Japanese. In J. Angouri, T. Harrison, S. Schnurr, \& S. Wharton (Eds.), Proceedings of the 47th BAAL Annual Meeting (pp. 29-36). London: BAAL.

Barrs, K. (2015). Errors in the use of English in the Japanese linguistic landscape. English Today, 31(4), 30-33.

Bennett, P., \& Stoeckel, T. (2014). Word frequency and frequency of loanwords as predictors of word difficulty. Vocabulary Education and Research Bulletin, $3(2), 4-5$.

Berendt, E., Kurosaki, E., Maeda, A., Matsui, K., \& Ochi, N. (2005). English loan words of Japanese elementary school children and their mental lexicon. Asian Englishes, 8(2), 26-45.

Brown, J. B. (1995). Is gairaigo English? The Internet TESL Journal, 1(2).

Daulton, F. E. (1998). Japanese Loanword cognates and the acquisition of English vocabulary. The Language Teacher, 22(1), 17-25. 
Daulton, F. E. (2003a). List of high-frequency baseword vocabulary for Japanese EFL students \#2. The Internet TESL Journal, 9(3).

Daulton, F. E. (2003b). Loanwords in the media. Ryukoku International Center Research Bulletin, 12, 17-31.

Daulton, F. E. (2003c). The effect of Japanese loanwords on written English production-A pilot study. JALT Hokkaido Journal, 7, 4-14.

Daulton, F. E. (2004a). The creation and comprehension of English loanwords in the Japanese media. Journal of Multilingual and Multicultural Development, 25(5), 285-296.

Daulton, F. E. (2004b). The importance of a high-frequency built-in lexicon for EFL in Japan. Ryukoku International Center Research Bulletin, 13, 69-80.

Daulton, F. (2005). Common gairaigo corresponding to high-frequency and academic English - Are Japanese students ready for foreign study? JALT Hokkaido Journal, 9, 1-16.

Daulton, F. E. (2007). Japanese learners' built-in lexicon of English and its effect on L2 production. The Language Teacher, 31(9), 15-18.

Daulton, F. E. (2008a). Japan's built-in lexicon of English-based loanwords. Clevendon: Multilingual Matters.

Daulton, F. E. (2008b). The 'katakana filter' and cognate recognition in Japanese EFL. The Ryukoku Journal of Humanities and Sciences, 30(1), 1-10.

Daulton, F. E. (2010). High-frequency English-based loanword cognates for EFL in Japan. Asian Journal of English Language Teaching, 20, 65-80.

Daulton, F. E. (2011). On the origins of gairaigo bias: English learners' attitudes towards English-based loanwords in Japan. The Language Teacher, 35(6), 7-12.

Dupoux, E., Kakehi, K., Hirose, Y., Pallier, C., \& Mehler, J. (1999). Epenthetic vowels in Japanese: A perceptual illusion? Journal of Experimental Psychology: Human Perception and Performance, 25, 1568-1578.

Ferreira, D. (2011). The use of loanwords in the Japanese EFL classroom. Ferris Studies, 46, 359-371.

Goddard, J. (2018). Recognition of English Loanwords (wasei-eigo) Among Japanese University Students. Kitasato Review, Annual Report of Studies in Liberal Arts and Sciences, 22, 59-66.

Haarmann, H. (1986). Verbal strategies in Japanese fashion magazines: A study in impersonal bilingualism and ethnosymbolism. International Journal of the Sociology of Language, 58, 107-121.

Hatanaka, M., \& Pannell, J. (2016). English loanwords and made-in-Japan English in Japanese. Hawaii Pacific University TESOL Working Paper Series, 14, $14-29$.

Hayashi, T., \& Hayashi, R. (1995). A cognitive study of English loanwords in Japanese discourse. World Englishes, 14(1), 55-56.

Hoffer, B. (1990). English loanwords in Japanese: Some cultural implications. Language Sciences, 12(1), 1-21. 
Hoffer, B. L., Beard, G. Y., \& Honna, N. (1983). Japanese use of English loans, Papers in Linguistics, 16(1-2), 35-56.

Hogan, J. (2003). The social significance of English usage in Japan. Japanese Studies, 23(1), 43-59.

Honna, N. (1995). English in Japanese society: Language within language. Journal of Multilingual and Multicultural Development, 16(1-2), 45-62.

Hoshino, N., \& Kroll, J. F. (2008). Cognate effects in picture naming: Does cross-linguistic activation survive a change of script? Cognition, 106, 501-511.

Hyde, B. (2002). Japan's emblematic English. English Today, 18(1), 3-7.

Igarashi, Y. (2007). The changing role of katakana in the Japanese writing system. Saarbrücken, Germany: VDM Verlag.

Inagawa, M. (2007). Influence of loanwords on English usage by Japanese learners of English. KATE Bulletin, 21, 85-96.

Inagawa, M. (2014). A re-examination of loanwords as an aid for English language learning and teaching. International Journal of Liberal Arts and Social Science, 2(3), 13-26.

Irwin, M. (2011). Loanwords in Japanese. Amsterdam: John Benjamins.

Ishikawa, K., \& Rubrecht, B. G. (2008). English loanword use in Japanese television. In K. Bradford Watts, T. Muller, \& M. Swanson (Eds.), JALT2007 Conference Proceedings. Tokyo: JALT.

Ishikawa, K., \& Rubrecht, B. G. (2009). Part-of-speech shift in English loanword adoption. In A. M. Stoke (Ed.), JALT2008 conference proceedings. Tokyo: JALT.

Iwasaki, Y. (1994) Englishization of Japanese and acculturation of English to Japanese culture. World Englishes, 14(1), 261-272.

Jordan, E. (2012). Cognates in vocabulary size testing-a distorting influence? Language Testing in Asia, 2(3), 5-17.

Kaneko, E., \& Iverson, G. K. (2009). Phonetic and other factors in Japanese online adaptation of English final consonants. In S. Inagaki \& M. Hirakawa (Eds.), Studies in language sciences (p. 8). Tokyo: Kurosio.

Kay, G. (1995). English loanwords in Japanese. World Englishes, 14(1), 67-76.

Kay, G. (1986). The English in Japanese. English Today, 6, 25-27.

Koscielecki, M. (2006). Japanized English, its context and socio-historical background. English Today, 22(4), 25-31.

Kowner, R., \& Rosenhouse, J. (2001). Cultural policy on loanword adoption in modern Japanese and Hebrew: A comparative study. Cultural Policy, 7(3), 521-548.

Kurahashi, Y. (2011). The use of English loanwords in the Japanese language: A study on Learning English vocabulary from English loanwords. JACET Chubu Journal, 9, 109-123.

Laufer, B., \& McLean, S. (2016). Loanwords and vocabulary size test scores: A case of different estimates for different L1 learners. Language Assessment Quarterly, 13(3), 202-217. 
Loveday, J. (1996). Language contact in Japan. Oxford: OUP.

Kubozono, H. (2002). Prosodic structure of loanwords in Japanese: Syllable structure, accent and morphology. Journal of the Phonetic Speech Society of Japan, 6(1), 79-97.

Kubozono, H. (2006). Where does loanword prosody come from? A case study of Japanese loanword accent. Lingua, 116(7), 1140-1170.

Lupker, S. J., Nakayama, M., \& Perea, M. (2015). Is there phonologically based priming in the same-different task? Evidence from Japanese-English bilinguals. Journal of Experimental Psychology: Human Perception and Performance, 41(5), 1281-1299.

MacGregor, L. (2003). The language of shop signs in Tokyo. English Today, 19(1), $18-23$.

Mackenzie, A. (2014). An examination of loanword cognates, false friends and synformy. Keieironshu, 84, 95-104.

Martin, A. (2004). The 'katakana effect' and teaching English in Japan. English Today, 20(1), 50-55.

Masson, M. E. (2013). How L1 loanwords can create a false sense of familiarity with L2 vocabulary meaning and usage. Vocabulary Learning and Instruction, 2(1), 8-14.

Matsuda, A. (2003). The Ownership of English in Japanese Secondary Schools. World Englishes, 22(4), 483-496.

McKenzie, R. M. (2008). The complex and rapidly changing sociolinguistic position of the English language in Japan: A summary of English language contact and use. Japan Forum, 20(2), 267-286.

Meerman, D., \& Tamaoka, K. (2009). Japanese university EFL student understanding of commonly-used Japanized-English (wasei-eigo) expressions. Kurume University Bulletin of the Institute of Foreign Language Education, $16,19-40$.

Mielick, M. (2017). Exploring Japanese university students' fear of English loanword use in the Japanese media. Thai TESOL Journal, 30(1), 1-27.

Millar, N. (2006). The use of Japanese loanword cognates in Japanese ESL learners' production: A corpus-based study. Journal of Kanda University of International Studies, 18, 479-496.

Miwa, K., Dijkstra, T., Bolger, P., \& Baayen, H. (2014). Reading English with Japanese in mind: Effects of frequency, phonology, and meaning in different-script bilinguals. Bilingualism: Language and Cognition, 17(3), 445-463.

Mizumoto, A., \& Shimamoto, T. (2008). A comparison of aural and written vocabulary size of Japanese EFL university learners. Language Education \& Technology, 45, 35-52.

Moody, A. J. (2006). English in Japanese popular culture and J-Pop music. World Englishes, 25(2), 209-222. 
Morrow, P. R. (1987) The users and uses of English in Japan. World Englishes, 6(1), 49-62.

Nagasawa, J. (1958). A study of English-Japanese cognates. Language Learning, $8,53-102$.

Nakao, M. (2013). What does knowing a loanword mean for Japanese students? Vocabulary Education and Research Bulletin, 2(2), 13-15.

Nakao, K. (2016). Loanwords for language learners: Help or hindrance? Vocabulary Learning and Instruction, 5(1), 18-28.

Nakayama, M., Sears, C. R., Hino, Y., \& Lupker, S. J. (2012). Cross-script phonological priming for Japanese-English bilinguals: Evidence for integrated phonological representations. Language and Cognitive Processes, 27(10), $1563-1583$.

Nakayama, M., Sears, C. R., Hino, Y., \& Lupker, S. J. (2013). Masked translation priming with Japanese-English bilinguals: Interactions between cognate status, target frequency and L2 proficiency. Journal of Cognitive Psychology, 25(8), 949-981.

Nakayama, M., Verdonschot, R. G., Sears, C. R., \& Lupker, S. J. (2014). The masked cognate translation priming effect for different-script bilinguals is modulated by the phonological similarity of cognate words: Further support for the phonological account. Journal of Cognitive Psychology, 26(7), 714-724.

Nobis, J. (2012). Gairaigo and manga: An ongoing literacy study of loanwords found in comic books. Vocabulary Education and Research Bulletin, 1(1), 6-7.

Nomura, J., \& Ishikawa, K. (2018). Effects of first language processes and representations on second language perception: The case of vowel epenthesis by Japanese speakers. International Journal of Bilingualism, 22(1), 69-87.

Norman, J. (2012). Japanese university student awareness of wasei-eigo. In A. Stewart \& N. Sonda (Eds.), JALT 2011 Conference Proceedings. Tokyo: JALT.

Ogasawara, M. (2008). The importance of raising awareness of English loanwords in Japanese. Journal of Aomori University of Health and Welfare, 9(1), 29-34.

Olah, B. (2007). English Loanwords in Japanese: Effects, Attitudes and Usage as a Means of Improving Spoken English Ability. Journal of the Faculty of Human studies, Bunkyo Gakuin University, 9(1), 177-188.

Ozaki, S. (2014). Notes on English loanwords in Japanese: Major sound transformations. Journal of Nagoya Bunri University, 15, 29-40.

Peperkamp, S., Vendelin, I., \& Nakamura, K. (2008). On the perceptual origin of loanword adaptations: Experimental evidence from Japanese. Phonology, 25(1), 129-164.

Racine, J. P. (2008). Cognitive processes in second language word association. JALT Journal, 30(1), 5-26.

Racine, J. P. (2011). Loanword associations and processes. Outside the Box: The Tsukuba Multi-Lingual Forum, 4(1), 37-45. 
Rebuck, M. (2002). The function of English loanwords in Japan. NUCB JLCC, $4(1), 53-64$.

Rebuck, M. (2007). Raising awareness of English loanwords in Japanese. The Language Teacher, 31(9), 24-26.

Ringbom, H. (2007). The importance of cross-linguistic similarities. The Language Teacher, 31(9), 3-5.

Rogers, J., Bonnah, T., Daulton, F., DuQuette, J.P, \& Montgomery, P. (2017). On Unreliability and Inefficiency in Word Lists. Osaka JALT Journal, 4, 83-94.

Rogers, J., Webb, S., \& Nakata, T. (2014). Do the cognacy characteristics of loanwords make them more easily learned than noncognates? Language Teaching Research, 19(1), 9-27.

Rouault, G., \& Okamoto, A. (2010). Loanwords in Japanese fashion magazines. Kwansei Gakuin University Humanities Review, 14, 101-116.

Seargeant, P. (2005). Globalisation and reconfigured English in Japan. World Englishes, 24(3), 309-319.

Seaton, P. (2001). 'Shampoo for extra damage': Making sense of Japanized English. Japan Forum, 13(2), 233-247.

Sheperd, J. (1996). Loanwords: A pitfall for all students. The Internet TESL Journal, 2(2). Retrieved from http://iteslj.org/Articles/Shepherd-Loanwords. html

Sherry, J. F., \& Camargo, E. G. (1987). "May your life be marvelous:” English Language labelling and the semiotics of Japanese promotion. Journal of Consumer Research, 14(2), 174-188.

Shibatani, M. (1990). The languages of Japan. New York: Cambridge University Press.

Simon-Maeda, A. (1995). Language awareness: Use/misuse of loan-words in the English language in Japan. The Internet TESL Journal, 1(2). Retrieved from http://iteslj.org/Article/Maeda-Loanword.html

Smith, D. (1974). Ribbing Ingrish: Innovative borrowing in Japanese. American Speech, 49(3/4), 185-196.

Smith, J. L. (2006). Loan phonology is not all perception: Evidence from Japanese loan doublets. In T. J. Vance \& K. A. Jones (Eds), Japanese/Korean Linguistics 14. Stanford: CSLI.

Smith, S. J. (1997). Katakana is not English. The Language Teacher (Online), 21(1). Retrieved from http://jaltpulication.org/old_tlt/files/97/jan/katakana.html

Spring, M. (2018). Unconscious gairaigo bias in EFL: A case study of Japanese teachers of English. Shinshu University Journal of Arts and Sciences, 12, $166-181$.

Stanlaw, J. (1987). Japanese and English: Borrowing and contact. World Englishes, 6(2), 93-109.

Stanlaw, J. (2004). Japanese English language and culture contact. Hong Kong: Hong Kong University Press. 
Stoeckel, T., \& Bennett, P. (2013). Sources of differential item functioning between Korean and Japanese examinees on a second-language vocabulary test. Vocabulary Learning and Instruction, 2(1), 47-55.

Struc, N., \& Wood, N. (2015). Cross-linguistic lexical transfer of English-based loanwords in English L2 writing by Japanese university students. Bergen Language and Linguistics Studies, 6, 5-22.

Stubbe, R. (2010). Exploring the lexical challenge of the TOEIC® Bridge. In A. M. Stoke (Ed.), JALT2009 Conference Proceedings. Tokyo: JALT.

Stubbe, R. (2014). Do Japanese students overestimate or underestimate their knowledge of English loanwords more than non-loanwords on yes-no vocabulary tests? Vocabulary Learning and Instruction, 3(1), 29-43.

Stubbe, R., Hoke, S., \& O’Sullivan, C. (2013). University student knowledge of loanwords versus nonloanwords. In N. Sonda \& A. Krause (Eds.), JALT2012 Conference Proceedings. Tokyo: JALT.

Stubbe, R., \& Yokomitsu, H. (2012). English loanwords in Japanese and the JACET 8000. Vocabulary Education and Research Bulletin, 1, 10-11.

Sumiya, H., \& Healy, A. F. (2008). The Stroop Effect in English-Japanese Bilinguals: The Effect of Phonological Similarity. Experimental Psychology, 55, 93-101.

Taft, M. (2002). Orthographic Processing of Polysyllabic Words by Native and Nonnative English Speakers. Brain and Language, 81, 532-544.

Takahashi, K. (1990). A sociolinguistic analysis of English borrowings in Japanese advertising texts. World Englishes, 9(3), 327-341.

Tamaoka, K., \& Miyaoka, Y. (2003). The cognitive processing of Japanese loanwords in katakana. Japanese Psychological Research, 45(2), 69-79.

Tomoda, T. (1999). Impact of loan-words on modern Japanese. Japan Forum, 11(1), 231-253.

Tosa, T. (2017). A Tentative Classification of Rhetoric in Japanese Linguistic Expressions in Advertising Contexts. OTB Forum, 8(1), 25-29.

Uchida, E. (2001). Audio and visual identification of unknown L2 cognates involving different scripts. Essex Graduate Student Papers in Language and Linguistics (University of Essex, Department of Language \& Linguistics), 3, 211-230.

Uchida, E. (2007). Oral and written identification of L2 loanword cognates by initial Japanese learners of English. The Language Teacher, 31(9), 19-22.

Van Benthuysen, R. (2004). Japanese EFL students' awareness of English loanword origins. Journal of Bunkyo Gakuin University, 4, 169-174.

Van Benthuysen, R. (2010). Japanese ESL learners' acquisition of English loanword cognates: Difficulties due to semantic, phonological, and orthographic factors. Journal of Bunkyo Gakuin University, 10, 255-263.

Vendelin, I., \& Peperkamp, S. (2004). Evidence for phonetic adaptation of loanwords: an experimental study. Actes des Journées d'Etudes Linguistiques, $129-131$. 
Weber, A., Broersma, M., \& Aoyagi, M. (2011). Spoken-word recognition in foreign-accented speech by L2 listeners. Journal of Phonetics, 39(4), 479-491.

Willis, M., \& Ohashi, Y. (2012). A model of L2 vocabulary learning and retention. The Language Learning Journal, 40(1), 125-137.

Yazawa, K., Konishi, T., Hanzawa, K., Short, G., \& Kondo, M. (2015). Vowel epenthesis in Japanese speakers' L2 English. In: Proceedings of the 18th International Congress of Phonetic Sciences. London: International Phonetic Association.

Yokokawa, H. (2009). English word familiarity of Japanese learners of English, Audio Edition: Second language research database for education and research. Tokyo: Kuroshio.

Zeserson, J. M. (2001). How Japanese women talk about hot flushes: Implications for menopause research. Medical Anthropology Quarterly, 15(2), 189-205. 